\title{
Ideology and Deliberation : An Analysis of Public Support for Deliberative Practices in Finland
}

\section{Christensen, Henrik Serup}

2019-03-01

Christensen, H S \& von Schoultz , A A-L 2019 , ' Ideology and Deliberation : An Analysis of Public Support for Deliberative Practices in Finland ' , International Journal of Public Opinion pÿResearch , vol. 31 , no. 1 , pp. 178194 . https://doi.org/10.1093/ijpor/edx022

http://hdl.handle.net/10138/309546

https://doi.org/10.1093/ijpor/edx022

acceptedVersion

Downloaded from Helda, University of Helsinki institutional repository.

This is an electronic reprint of the original article.

This reprint may differ from the original in pagination and typographic detail.

Please cite the original version. 
IDEOLOGY AND DELIBERATION

Accepted for publication in International Journal of Public Opinion Research

https://academic.oup.com/ijpor/advance-

article/doi/10.1093/iipor/edx022/4841890?guestAccessKey=2dc2cd1c-b7cc-48e7-a0b6-

$\underline{87 f d 99 f 5693 a}$

[Published version may differ slightly]

Henrik Serup Christensen \& Åsa von Schoultz

IDEOLOGY AND DELIBERATION:

AN ANALYSIS OF PUBLIC SUPPORT FOR DELIBERATIVE PRACTICES IN FINLAND

Abstract

Deliberative practices have been suggested as a way to increase involvement in political decision making, although it is unclear whether such practices appeal to all segments of society. For this reason, we examine the links between support for deliberative practices and two dimensions of ideological predispositions: left-right ideology and nationalism-cosmopolitanism. Analyses based on data from the 2015 Finnish National Election Study (FNES2015) with 1602 respondents, demonstrate that citizens with leftist and cosmopolitan predispositions are more supportive of deliberative practices. Furthermore, political awareness moderates the impact of the left-right ideological dimension, suggesting that individuals who are politically aware are better equipped to convert their left-right predispositions into opinions towards deliberative practices.

Keywords: deliberative democracy, ideology, political participation, process preferences, democratic innovations, political awareness 
IDEOLOGY AND DELIBERATION

The introduction of deliberative practices has been proposed as a method for revitalizing representative democracies suffering from decreasing political involvement and increasing fragmentation (Dryzek, 2000; Grönlund, Bächtiger, \& Setälä, 2014; Parkinson \& Mansbridge, 2012). Some scholars, however, question whether citizens are willing to engage in deliberative practices (Bartels, 2003; Hibbing \& Theiss-Morse, 2002; Posner, 2004). A related concern is that deliberative practices may not appeal equally to all groups of citizens, and consequently jeopardize the principle of inclusion of all relevant arguments and experiences in deliberation (Young, 2000).

Whether deliberative practices can help revitalize democracy partly depends on the extent to which support for these practices is related to ideological predispositions. Previous studies suggest that ideological predispositions systematically influence individual attitudes toward public involvement in political processes (Bengtsson \& Mattila, 2009; Dalton \& Welzel, 2014; Inglehart, 1997; Kriesi, 2010). If a corresponding pattern were to be found for deliberative practices, the result could be detrimental to the deliberative focus on inclusiveness. An ideological bias among supporters might translate into overrepresentation of certain ideological perspectives in deliberative events. Furthermore, if support for deliberative practices depends on strong ideological predispositions, the prospective participants in deliberation are likely to behave like activists-eager to pursue their established goals by any means necessary (Mackuen, Wolak, Keele, \& Marcus, 2010, p. 440)-rather than deliberative citizens, who are considerate, balanced, open-minded, and willing to compromise (Levine \& Nierras, 2007; Mackuen et al., 2010). If the composition of deliberative events is ideologically unrepresentative, it can also result in harmful group composition effects that affect the final outcome (Baek, Wojcieszak, \& Delli Carpini, 2012; Barabas, 2004; Gastil, Black, \& Moscovitz, 2008). It is therefore important to establish how ideological predispositions shape attitudes toward the use of deliberative practices in society.

Based on these considerations, we aim to study how support for deliberative practices is linked to ideological predispositions on the traditional left-right dimension and the nationalist-cosmopolitan values dimension. Jacobs, Cook, \& Delli Carpini (2009) and Neblo, Esterling, Kennedy, Lazer, \& Sokhey (2010) constitute a couple of pioneering studies that examine the willingness to deliberate in the US, and show that politically marginalized groups are willing to deliberate (Neblo et al. 2010), and that self-identified liberals are more likely to engage in deliberation than people who consider themselves to be more conservatives (Jacobs et al. 2009). However, these studies are not necessarily applicable outside the American context. Moreover, Jacobs et al. (2009) restrict their analysis to a onedimensional conceptualization of ideology that fails to capture contemporary ideological richness.

We use the Finnish National Election Study from 2015 (FNES2015) to demonstrate that individuals who are left-leaning and/or adhere to cosmopolitan values support deliberative practices. 
IDEOLOGY AND DELIBERATION

In line with the work of Zaller (1992), we also find that political awareness furthers the ability to formulate opinions that are consistent with ideological predispositions.

\section{Deliberation and Ideological Predispositions}

Important distinctions can be made between different theories of deliberative democracy (Bächtiger, Niemeyer, Neblo, Steenbergen, \& Steiner, 2010), but they share an emphasis on discussions as prerequisites for enlightened political decision-making. In this study, we use the concept of deliberative practices to refer to a broad range of measures aiming to improve the deliberative capacity of political systems by promoting discussions and exchanges of arguments in society (Parkinson \& Mansbridge, 2012). There are various kinds of public discussions, some of which fail to fulfil the most stringent definitions of deliberation (Levine \& Nierras, 2007; Karpowitz \& Mendelberg, 2007). Nevertheless, we here employ a broad definition of deliberation since the aim is to include all processes that may enhance the deliberative capacity of political systems, even when they do not completely adhere to the ideal of deliberation. ${ }^{1}$

Successful deliberation ideally should include all relevant arguments and opinions, and be a formative process (Goodin, 2004; Mansbridge et al., 2010; Parkinson, 2006). In order to ensure that all relevant positions and perspectives are included, the ideological predispositions of participants in deliberative practices ought to reflect the ideological composition of society (Gastil 2008; Gastil et al., 2008; Young, 2000). It is however questionable whether deliberative practices appeal to all segments of society, especially when it comes to the ideological predispositions of presumptive supporters.

From a theoretical perspective, deliberation has been accused of harbouring an elitist notion of democracy that does not appeal to common people, and of promoting liberal values over more conservative ones (Blattberg 2003; Parvin, 2015). Empirical evidence also suggests that ideological predispositions affect support for deliberative practices. First, it is well-established that politically right-leaning individuals are more conservative when it comes to institutional changes (Anderson \& Singer, 2008, p. 574). Although deliberation may help preserve the status quo by blocking drastic political reforms, those on the right may consequently oppose such novel methods of decision making. Furthermore, previous studies have found that people are generally consistent in their preferences of decision-making procedures (Bengtsson \& Christensen, 2016; Bengtsson \& Mattila, 2009; Font, Wojcieszak, \& Navarro, 2015). Some studies even suggest that leftists show stronger support for participatory and direct democratic processes (Bengtsson \& Mattila, 2009; Esaiasson, Gilljam, \& Persson, 2010), and they may likewise be more inclined towards deliberative practices.

Second, the progression of what has been termed postmodernist, libertarian or cosmopolitan values in Western democracies is tied to support for participatory reforms (Dalton \& Welzel, 2014; Inglehart, 1997; Kriesi, 2010). According to Inglehart (1977, 1997), post-materialist generations crave innovative forms of political participation to complement the traditional representative structures. 
IDEOLOGY AND DELIBERATION

Third, studies on deliberation show that certain ideological positions dominate deliberative events. Jacobs et al. (2009, p. 53) found that liberals are more likely than conservatives to engage in deliberation, and a study of recruitment to a deliberative mini-public shows that attrition is higher among citizens with anti-immigration attitudes (Karjalainen \& Rapeli, 2015). ${ }^{2}$

Political ideology, as we use the term here, departs from dominant issue divides with political relevance (Bartolini, 2011; Deegan-Krause, 2007). Traditionally, ideology has been considered a onedimensional phenomenon distributed on a left-right continuum (Downs, 1957), which in a European context has its roots in historical class cleavages (Lipset \& Rokkan, 1967; Knutsen, 2006) that divided politics into the liberal-conservative right and the social-democratic or socialist left. Although this leftright dimension has largely revolved around issues of redistribution, over time it has developed into a meta-dimension that has structured party systems and the ideological beliefs of citizens (Mair, 2007).

However, several works contend that ideology can no longer be considered one-dimensional, and that a dimension concerning immaterial values rather than issues of redistribution has complemented the left-right dimension. Scholars here use various labels to denote the poles on closely related value dimensions, such as libertarian/authoritarian (Flanagan \& Lee, 2003; Kitschelt, 1994, 1995), post-materialist/materialist (Inglehart, 1977), green-alternative-libertarian (GAL)/traditional-authoritarian-nationalist (TAN) (Hooghe, Marks, \& Wilson, 2002) or cosmopolitans/nationalists (Norris \& Inglehart, 2009). ${ }^{3}$ Despite the different labels and empirical operationalizations, these scholars share a belief that when examining the causes and consequences of ideological predispositions, it should be acknowledged that ideology today is a multi-dimensional phenomenon. For this reason, we also examine the relationship between the dimension that we label national-cosmopolitan values and support for deliberative practices.

The theoretical and empirical reasons presented above suggest that ideological predispositions on both dimensions are likely to influence attitudes towards deliberative practices, since individuals with more leftist and/or cosmopolitan values are likely to support the introduction of such mechanisms to complement representative decision making. These suggestions are in line with the established finding that general political predispositions function as guides or heuristic devices when people structure their views on more specific issues (Feldman \& Zaller, 1992; Goren, Schoen, Reifler, Scotto, \& Shittick, 2016; Sniderman, Brody, \& Tetlock, 1991). However, the impact of these predispositions may be less straightforward than suggested above. As convincingly demonstrated by Zaller (1992), people need a certain level of political awareness (attention and understanding) in order to translate their ideological predispositions into opinions on specific issues. ${ }^{4}$ Politically aware citizens are more likely to organize their political ideas in an ideologically consistent manner 5 (Gastil \& Dillard, 1999), that is, they are more likely to hold political beliefs that are in line with their ideological 
IDEOLOGY AND DELIBERATION

predispositions. This implies that it is among the politically aware that we would expect to find a stronger link between ideological predispositions and attitudes towards deliberative practices.

Based on these considerations, we examine the following hypotheses on the relationship between ideological predispositions and support for deliberative practices in the empirical section: H1. Leftist values on the traditional left-right dimension are positively associated with positive attitudes towards deliberative practices.

H2. Cosmopolitan values on the nationalist-cosmopolitan dimension are positively associated with positive attitudes towards deliberative practices.

H3. Political awareness moderates the relationship between ideological predispositions and attitudes towards deliberative practices.

\section{Data and Operationalizations}

The data come from the Finnish National Election Study conducted following the national elections on 19 April 2015 (FNES2015), which involved a cross-sectional survey using a two-stage process with introductory face-to-face interviews of 1,602 respondents during April-June $2015 .{ }^{6}$ Although the cross-sectional data do not make it possible to settle causal effects, FNES2015 is ideal for examining associations between ideological predispositions and support for deliberative practices since the survey includes suitable measures for all variables.

Finland constitutes an opportune case since, like most European democracies, it has an established tradition of representative decision making complemented by a restrictive use of consultative referendums. However, studies show demand for more citizen involvement in political decision making (Bengtsson \& Christensen, 2016), echoing similar sentiments across the continent. In this sense, even though the generalizability of the results may be limited, Finland presents a paradigmatic case for studying attitudes towards deliberative practices. The general public has a limited familiarity with formal deliberative institutions such as deliberative mini-publics. ${ }^{7}$ However, this does not preclude the public from forming opinions on the presumptive use of deliberative practices in the form of public discussions to complement representative decision making.

All variables are coded to vary between 0 and 1 , with 1 indicating the highest value of the variable in question. More information on the coding of variables, and descriptive statistics, is found in Appendix 1.

\section{Dependent Variable}

The dependent variable is the attitude towards the use of deliberative practices as a complement to representative decision making. ${ }^{8}$ The measure is based on responses to two statements: 1) Political discussions for ordinary citizens should be arranged in support of representative democracy, and 2) I myself would like to participate in political discussions arranged for ordinary citizens. The responses to both items were indicated using a 4-point Likert scale (totally 
IDEOLOGY AND DELIBERATION

agree-totally disagree), and these scores were subsequently combined to form an additive index ( $M=$ .53). A closer inspection of the individual questions (not shown) reveals that about $75 \%$ tend to agree that discussions should be arranged to support representative democracy, while only about $42 \%$ are willing to take part in them. ${ }^{9}$

Our operationalization is based on a broad conceptualization of deliberative practices in line with the definition offered above, and may therefore overestimate the extent of support for a more narrowly defined interpretation. Some may even object to the label deliberative practices since the questions do not refer to genuine deliberative institutions such as mini-publics (Grönlund et al., 2014). However, since most people are unfamiliar with these formal deliberative institutions, it makes little sense to ask respondents about their attitudes towards them directly. Previous survey research on how citizens see public deliberation has also relied on similarly wide understandings of the topic (Baek et al., 2012; Wojcieszak, Baek, \& Delli Carpini, 2009).

A broad conceptualization is warranted in this case, as the objective is not to identify support for specific arrangements (i.e., mini-publics), but to examine support for the use of talk-centric measures to improve representative decision making. Our conceptualization is closer to what Bächtiger et al. (2010) entitle Type II deliberation, which involves more flexible discourses than the more narrowly defined Type I deliberation, which focuses on rational discourse and procedural aspects. Nevertheless, our operationalization entails a focus on discussions that are connected to formal political decision making in line with Levine \& Nierras (2007).

\section{Independent Variables}

To capture ideological predispositions, we focused on the traditional left-right dimension (Mair, 2007) and the increasingly important dimension of what we here refer to as nationalist-cosmopolitan values. The position on the left-right dimension was measured with a variable, where the respondent indicated his or her placement on an 11-point left-right scale (recoded to vary between 0-1 (1=right). The degree of national-cosmopolitan values was captured with an index based on three questions measuring the attitudes of the respondents towards multiculturalism in general and tolerance towards two out-groups: sexual minorities and immigrants (Cronbach's alpha=.76, 1=cosmopolitan) 10.

\section{Moderator Variables}

Political awareness is conceptualized as the understanding of and attentiveness towards politics, and operationalized by two different variables. The first is factual political knowledge, which is in accordance with the operationalization used by Zaller (1992). This was measured with an index, where respondents received a point for each correct answer to five factual questions on international and domestic Finnish political matters ( $0=$ no correct answers). The second variable is political interest, 
IDEOLOGY AND DELIBERATION

which has been considered a suitable indicator (Zaller, 1992, pp. 333-4) and has been used in previous research on similar topics (Verba, Schlozman, \& Brady, 1995). We measured this with a common question on the topic, where respondents indicated how interested they were in politics on a 4-point scale $(0=$ lowest interest $)$.

\section{Control Variables}

To ascertain the robustness of the results, we included socio-demographic characteristics (age, gender, education and full-time employment) and attitudes towards the political system (satisfaction with democracy, political trust, and internal and external political efficacy). All of these variables have been demonstrated to influence the propensity for political participation in general (Bengtsson \& Christensen, 2016; Verba et al., 1995) and in regard to deliberation (Karjalainen \& Rapeli, 2015; Neblo et al., 2010).

Age in years was divided by 100 to approximate the $0-1$ coding of all independent variables. In regard to education, the respondents indicated the highest level of education completed on an 8point scale ( $0=$ lowest level of education). The other two characteristics are dichotomous. For gender, 0 indicates female and 1 male, whereas for employment, 1 corresponds to full-time employment, and all other occupations (student, retired, half-time employment etc.) are coded 0 . For satisfaction with democracy, respondents indicated their extent of satisfaction with how democracy functions in Finland on a 4-point scale ( $0=$ =lowest satisfaction). We measured internal political efficacy with a question, where respondents indicated the extent to which they agree with the statement, "Sometimes politics seems so complicated that I can't really understand what is going on," on a 4point Likert scale ( $0=$ lowest efficacy). External efficacy was measured with an index based on four statements, where respondents indicated their views on the responsiveness of the political system on a 4-point Likert scale $(0=$ lowest efficacy ; Cronbach's alpha $=.77)$. For political trust, we use an index based on five questions, where respondents indicated their level of trust on an 11-point scale (0-10) in regard to the Finnish parliament, politicians, political parties, the Finnish president, and the government (Cronbach's alpha=.91).

\section{Methods of Analysis}

A Shapiro-Wilk test shows that the dependent variable follows a normal distribution since the null hypothesis cannot be rejected $(W=0.998 ; p=.0812)$. We therefore used linear regression with robust standard errors to examine our hypotheses. To examine $\mathrm{H} 1$ and $\mathrm{H} 2$ concerning the associations between ideological factors and support for deliberative practices, the first model, M1, only included the two ideological factors, left-right and nationalist-cosmopolitan, whereas M2 also included the measures of political awareness and control variables to verify that the linkages persist when controlling for other factors. 
IDEOLOGY AND DELIBERATION

To examine $\mathrm{H} 3$ and the moderating effect of political awareness, in $\mathrm{M} 3$, we included four interaction terms constituted by the two ideological factors and the two factors of political awareness in the regression model.

\section{Empirical Analysis}

Table 1 displays the results of the regression analyses.

\section{TABLE 1 ABOUT HERE}

M1 shows that both ideological variables have the expected relationships with support for deliberative practices, which is also the case for $\mathrm{M} 2$ after controlling for other variables. For the leftright dimension, the negative coefficient of -0.21 in $\mathrm{M} 2(p<.001)$ shows that being to the left on this ideological dimension is associated with stronger support for deliberative practices. For the nationalist-cosmopolitan dimension, the positive coefficient of $0.12(p=.002)$ shows that a higher degree of cosmopolitanism is associated with stronger support for deliberative practices. Figures $1 \mathrm{a}$ and $1 \mathrm{~b}$ show what this entails for the associations between ideological factors and support for deliberative practices when holding all other factors at their mean values.

\section{FIGURE 1 ABOUT HERE}

For the left-right dimension, the predicted value of support for deliberative practices is about 0.66 for those furthest to the left, but this decreases to about 0.45 for the most extreme rightist respondents. For the nationalist-cosmopolitan dimension, the most nationalist respondents have a predicted level of support of about 0.47 , which increases to 0.59 for the respondents with the most cosmopolitan values. This supports $\mathrm{H} 1$ and $\mathrm{H} 2$, since both ideological variables have the expected associations with level of support for using deliberative practices.

M3 shows that there are no significant effects for the nationalist-cosmopolitan dimension. There is, however, a significant interaction effect between the left-right dimension and political interest and the interaction effect between the left-right dimension and political knowledge is marginally insignificant $(B=-0.25, p=.072)$. Since traditional significance tests are unreliable for establishing the substantial importance of interaction effects, we show the implications of both of these in Figure 2 (Bedeian \& Mossholder, 1994; Brambor, Clark, \& Golder, 2006). ${ }^{11}$ To allow for a comprehensive examination of what the plots signify, we included both marginal effects of left-right ideology depending on political awareness and developments in predicted support for deliberative practices for those furthest to the left and those furthest to the right. 
IDEOLOGY AND DELIBERATION

\section{FIGURE 2 ABOUT HERE}

The substantive interpretations were similar regardless of whether we measured political awareness with political interest or political knowledge. At lower levels of political awareness, the associations between the left-right dimension and support for deliberative practices are negligible, but they strengthen when respondents become politically aware. Hence leftist individuals are only supportive of deliberative practices when they also pay attention to what happens in politics.

The results thereby partly support $\mathrm{H} 3$ since the associations between the left-right dimension and support for deliberative practices depend on the level of political awareness, whereas there are no moderating effects for the nationalist-cosmopolitan dimension.

\section{Implications of Results}

The main finding presented here is that support for deliberative practices is higher among individuals with leftist and/or cosmopolitan values. If this support were to be reflected in actual participation, it would challenge the inclusiveness of deliberative practices emphasized by several deliberative theorists (Mansbridge et al., 2010; Parkinson, 2006; Young, 2000). ${ }^{12}$ When deliberative practices mainly attract participants who hold certain ideological positions, the result can undermine both the quality and legitimacy of the output of deliberative practices (Dryzek, 2000; Goodin, 2004; James, 2008).

Our findings support previous studies that also found ideological predispositions to be associated with positive attitudes towards participatory mechanisms in general (Bengtsson \& Mattila, 2009; Dalton \& Welzel, 2014; Inglehart, 1997) and deliberative practices in particular (Jacobs et al., 2009). The results thus support the notion that those with leftist/cosmopolitan values favour participatory political processes, albeit other mechanisms specifically related to the deliberative character of the processes under scrutiny may also be in play. Some studies suggest that issues traditionally associated with the right or nationalism are considered less amenable to public scrutiny (Gastil et al., 2010, pp. 4-5), causing individuals who agree with these issues from the outset to be less likely to support the use of deliberative practices.

There is therefore a need to ensure that less popular, and maybe even more controversial, viewpoints are represented during prospective deliberative events. This is especially the case since previous studies suggest that group composition affects developments in attitudes during deliberation (Gastil et al., 2008; Karpowitz \& Mendelberg, 2007). When participants tend to hold similar ideological predispositions, it is less likely that they are exposed to different ideological perspectives, which some studies suggest is a prerequisite for genuine deliberation (Barabas, 2004). It becomes more likely that participants act as activists rather than deliberative citizens (Levine \& Nierras, 2007; Mackuen et al., 2010), which may ultimately undermine the legitimacy of such events. 
IDEOLOGY AND DELIBERATION

We have also demonstrated that the link between left-right values and support for deliberation is stronger among the politically aware. A greater understanding of, and attentiveness towards, politics hence furthers the ability to formulate opinions that are consistent with ideological predispositions (Zaller, 1992). This finding supports the appeal made by Zaller (1992, pp. 308-309), that it is important for researchers to consider that people can vary greatly in their abilities to act on their values and interests. In this case, this entails that individuals with low political awareness may not articulate the attitude towards deliberative practices that their ideological predispositions would suggest.

In connection to this, it is noteworthy that political awareness only moderated the relationship between the traditional left-right ideological dimension and support for deliberative practices. Although the implications of this are unclear, it shows that the new ideological dimension emphasizing cultural perspectives has a more straightforward relationship with support for deliberative practices, even for those with low levels of political awareness. It is, however, possible that this finding is due to the character of the operationalization of this ideological dimension. Whereas an established measure exists for the left-right dimension, for measuring the position on the nationalist-cosmopolitan dimension we had to rely on issue positions in the form of attitudes towards various out-groups. Although common in the literature, it is possible that this approach leads people to think about specific interactions with the mentioned groups, rather than the abstract ideological principles that are of central concern here. This suggests a need to develop a measure of this cultural dimension that is equivalent to the left-right self-placement variable.

These findings do not come without limitations. Although the Finnish case is instructive, it cannot be ascertained that similar findings would be found in other settings. Furthermore, it is worth reiterating that these findings do not necessarily entail support for specific deliberative institutions such as mini-publics, since our aim here was to examine support for a broader notion of deliberative practices. In order to assess whether similar results could be obtained in other contexts and for other practices, more research is needed. 


\section{References}

Anderson, C. J. \& Singer, M. M. (2008). The sensitive left and the impervious right: Multilevel models and the politics of inequality, ideology, and legitimacy in Europe. Comparative Political Studies, 41, 564-599. doi: 10.1177/0010414007313113

Baek, Y. M., Wojcieszak, M., \& Delli Carpini, M. X. (2012). Online versus face-to-face deliberation: Who? Why? What? With what effects?. New Media \& Society, 14(3), 363-383. doi: $10.1177 / 1461444811413191$

Barabas, J. (2004). How deliberation affects policy opinions. American Political Science Review, 98, 687-701. doi: 10.1017/S0003055404041425

Bartels, L. (2003). Democracy with attitudes. In M.B. MacKuen \& G. Rabinowitz (eds.), Electoral democracy (pp. 48-82). Ann Arbor, MI: University of Michigan Press.

Bartolini, S. (2011). Cleavages, social and political. In B. Badie, D. Berg-Schlosser \& L. Morlino (eds.), International encyclopedia of political science (pp. 276-282). Thousand Oaks: SAGE Publications.

Bedeian, A. \& Mossholder, K. (1994). Simple question, not so simple answer: Interpreting interaction terms in moderated multiple regression. Journal of Management, 20(1), 159-165. doi: $10.1177 / 014920639402000108$

Bengtsson, Å. \& Christensen, H. S. (2016). Ideals and actions: Do citizens' patterns of political participation correspond to their conceptions of democracy? Government and Opposition, 51(2), 234-260. doi: 10.1017/gov.2014.29

Bengtsson, Å. \& Mattila, M. (2009). Direct democracy and its critics: Support for direct democracy and stealth democracy in Finland. West European Politics, 32, 1013-1048. doi: $10.1080 / 01402380903065256$

Blattberg, C. (2003). Patriotic, not deliberative, democracy. Critical Review of International Social and Political Philosophy, 6(1), 155-174. doi: 10.1080/13698230510001702723

Brambor, T., Clark, W. R., \& Golder, M. (2006). Understanding interaction models: Improving empirical analyses. Political Analysis, 14(1), 63-82. doi: 10.1093/pan/mpi014

Bächtiger, A., Niemeyer, S., Neblo, M., Steenbergen, M. R. \& Steiner, J. (2010). Disentangling diversity in deliberative democracy: Competing theories, their blind spots and complementarities. Journal of Political Philosophy, 18(1), 32-63. doi: 10.1111/j.1467-9760.2009.00342.x

Christensen, H. S., Himmelroos, S. \& Grönlund, K. (2017). Does deliberation breed an appetite for discursive participation? Developments in attitudes towards deliberative practices after firsthand experience. Political Studies, 65(S1), 64-83. doi: 10.1177/0032321715617771

Dalton, R. J. \& Welzel, C. (eds.) (2014). The civic culture transformed: from allegiant to assertive citizens. Cambridge, MA: Cambridge University Press.

Deegan-Krause, K. (2007). New dimensions of political cleavage. In R. J. Dalton \& H.-D. Klingemann (eds.), Oxford handbook of political science (pp. 538-556). Oxford: Oxford University Press.

Dryzek, J. (2000). Deliberative democracy and beyond. Liberals, critics, contestations. Oxford: Oxford University Press.

Esaiasson, P., Gilljam, M. \& Persson, M. (2010). Medborgarnas demokratiuppfattningar. In S. Holmberg, L. Weibull \& H. Oscarsson (eds), Lycksalighetens ö (pp. 269-277). Göteborg: SOMinstitutet, Göteborgs universitet.

Feldman, S., \& Zaller, J. (1992). The political culture of ambivalence: Ideological responses to the welfare state. American Journal of Political Science, 36, 268-307. doi: 10.2307/2111433

Flanagan, S. C. \& Lee, A.-R. (2003). The new politics, cultural wars, and the authoritarian libertarian value change in advanced industrial democracies. Comparative Political Studies, 36, 235-270. doi: 10.1177/0010414002250664

Font, J., Wojcieszak, M., \& Navarro, C. J. (2015). Participation, representation and expertise: Citizen preferences for political decision-making processes. Political Studies, 63(1 suppl), 153-172. doi: 10.1111/1467-9248.12191

Gastil, J. (2008). Political communication and deliberation. London: Sage University Press. 
Gastil, J., Bacci, C. \& Dollinger, M. (2010). Is deliberation neutral? Patterns of attitude change during "The deliberative polls". Journal of Public Deliberation, 6(2), art. 3. Available at: http://www.publicdeliberation.net/jpd/vol6/iss2/art

Gastil, J. \& Dillard, J. P. (1999). Increasing political sophistication through public deliberation. Political Communication, 16, 3-23. doi: 10.1080/105846099198749

Gastil, J., Black, L., \& Moscovitz, K. (2008). Ideology, attitude change, and deliberation in small faceto-face groups. Political Communication, 25(1), 23-46. doi: 10.1080/10584600701807836

Goodin, R. E. (2004). Representing diversity. British Journal of Political Science, 34(3), 453-468. doi: $10.1017 /$ S0007123404000134

Goren, P., Schoen, H., Reifler, J., Scotto, T., \& Chittick, W. (2016). A unified theory of value-based reasoning and US public opinion. Political Behavior, 38, 977-997. doi: 10.1007/s11109-016-9344$x$

Grönlund, K., Bächtiger, A. \& Setälä, M. (2014). Deliberative mini-publics - Involving citizens in the democratic process. Colchester: ECPR Press.

Hibbing, J. R. \& Theiss-Morse, E. (2002). Stealth democracy: Americans' beliefs about how government should work. Cambridge, MA: Cambridge University Press.

Hooghe, L., Marks, G. \& Wilson, C. (2002). Does left/right structure party position on European integration?. Comparative Political Studies, 35, 965-989. doi: 10.1177/001041402236310

Inglehart, R. (1977). The silent revolution: Changing values and political styles among Western publics. Princeton, NJ: Princeton University Press.

Inglehart, R. (1997). Modernization and postmodernization: Cultural, economic, and political change in 43 societies, Princeton, NJ: Princeton University Press.

Inglehart, R., \& Welzel, C. (2005). Modernization, cultural change, and democracy: The human development sequence. Cambridge, MA: Cambridge University Press.

Jacobs, L. R., Cook, F. L. \& Delli Carpini, M. X. (2009). Talking together: Public deliberation and political participation in America. Chicago: Chicago University Press.

James, M. R. (2008) Descriptive representation in the British Columbia citizens' assembly. In M.E. Warren \& H. Pearse (eds.), Designing deliberative democracy: The British Columbia citizens' assembly (pp.106-126). Cambridge, MA: Cambridge University Press.

Karjalainen, M. \& Rapeli, L. (2015). Who will not deliberate? Attrition in a multi-stage citizen deliberation experiment. Quality \& Quantity, 49, 407-422. doi: 10.1007/s11135-014-9993-y

Karpowitz, C. F., \& Mendelberg, T. (2007). Groups and deliberation. Swiss Political Science Review, 13, 645-662. doi: 10.1002/j.1662-6370.2007.tb00092.x

Kitschelt, H. (1994). The transformation of European social democracy. Cambridge, MA: Cambridge University Press.

Kitschelt, H., in collaboration with A. J. McGann (1995). The radical right in Western Europe, Ann Arbor: University of Michigan Press.

Kriesi, H. (2010). Restructuration of partisan politics and the emergence of a new cleavage based on values. West European Politics, 33, 673-685. doi: 10.1080/01402381003654726

Knutsen, O. (2006). Class voting in Western Europe. A comparative longitudinal study. Lanham: Lexington.

Levine, P., \& Nierras, R. M. (2007). Activists' views of deliberation. Journal of Public Deliberation, 3(1), art. 4. Available at: http://www.publicdeliberation.net/jpd/vol3/iss1/art4

Lipset, S. M. \& Rokkan S. (eds.). Party systems and voter alignments: Cross-national perspectives. New York: Free Press.

Luskin, R. C. (1987). Measuring political sophistication. American Journal of Political Science, 31, 856899. doi: $10.2307 / 2111227$

MacKuen, M., Wolak, J., Keele, L., \& Marcus, G. E. (2010). Civic engagements: Resolute partisanship or reflective deliberation. American Journal of Political Science, 54, 440-458. doi: 10.1111/j.15405907.2010.00440.x 


\section{IDEOLOGY AND DELIBERATION}

Mair, P. (2007). Left-right orientations. In R.J. Dalton \& H-D. Klingemann (eds.), The Oxford handbook of political behaviour (pp. 206-222). Oxford: Oxford University Press.

Mansbridge, J., Bohman, J., Chambers, S., Estlund, D., Føllesdal, A., Fung, A., Lafont, C. \& Manin, B. (2010). The place of self-interest and the role of power in deliberative democracy. Journal of Political Philosophy, 18(1), 64-100. doi: 10.1111/j.1467-9760.2009.00344.x

Neblo, M. A., Esterling, K. M., Kennedy, R. P, Lazer, D. M. J. \& Sokhey, A. E. (2010). Who wants to deliberate - and why?. American Political Science Review, 104, 566-583. doi: $10.1017 /$ S0003055410000298

Norris, P. \& Inglehart, R. (2009). Cosmopolitan Communications. Cultural Diversity in a Globalized World. Cambridge: Cambridge University Press.

Parkinson, J. (2006). Deliberating in the real world: Problems of legitimacy in deliberative democracy. Oxford: Oxford University Press.

Parkinson, J. \& Mansbridge, J. (eds.) (2012). Deliberative systems - Deliberative democracy at the large scale. Cambridge, MA: Cambridge University Press.

Parvin, P. (2015). Is deliberative democracy feasible? Political disengagement and trust in liberal democratic states. The Monist, 9(4), 407-423. doi: 10.1093/monist/onv021

Posner, R. (2004, January/February). Smooth Sailing. Legal Affairs. Retrieved from: https://www.legalaffairs.org/issues/January-February-2004/feature_posner_janfeb04.msp.

Smith, G. (2009). Democratic innovations: Designing institutions for citizen participation. Cambridge, UK: Cambridge University Press.

Sniderman, P. M., Brody, R., \& Tetlock, P. E. (1991). Reasoning and choice: Explorations in political psychology. New York: Cambridge University Press.

Verba, S., Schlozman, K. L., \& Brady, H. E. (1995). Voice and equality: Civic voluntarism in American politics. Cambridge, MA: Harvard University Press.

Webb, P. (2013). Who is willing to participate, and how? Dissatisfied democrats, stealth democrats and populists in the UK. European Journal of Political Research, 52, 747-72. doi: 10.1111/14756765.12021

Wojcieszak, M. E., Baek, Y. M., \& Delli Carpini, M. X. (2009). What is really going on? Structure underlying face-to-face and online deliberation. Information, Communication \& Society, 12, 1080-1102. doi: 10.1080/13691180902725768 


\section{Endnotes}

${ }^{1}$ Contrary to others (Christensen, Himmelroos, \& Grönlund, 2017; Jacobs et al., 2009), we do not use the term discursive practices to stress that the discussions should involve more than "just talk", i.e., they should be connected to existing political processes and, at least potentially, affect their outcomes, which is in line with the systemic approach to deliberation (Parkinson and Mansbridge, 2012). Our approach corresponds to the focus of Levine \& Nierras (2007) on public deliberation that aims to resolve real problems.

${ }^{2}$ Moreover, Gastil, Bacci, \& Dollinger (2010) find that outcomes of deliberation tend to be biased towards cosmopolitan and collectivist beliefs.

${ }^{3}$ Other examples of labels used are self-expression/survival (Inglehart \& Welzel, 2005), libertarian, universalistic/traditionalist-communitarian (Bornschier, 2010), integration/demarcation (Kriesi, 2010).

${ }^{4}$ We would like to thank one of the anonymous reviewers for this suggestion.

${ }^{5}$ Or to have "politically sophisticated" belief systems (Luskin, 1987).

${ }^{6}$ See https://services.fsd.uta.fi/catalogue/FSD3067?lang=en\&study language=en for more information on FNES2015.

${ }^{7}$ Deliberative mini-publics have mainly been used in the form of academic experiments in Finland.

${ }^{8}$ We use the same measure as Christensen et al. (2017), who study whether participation in a deliberative mini-public enhances support for arranging public discussions in representative democracy.

${ }^{9}$ We fitted ordinal regression models examining the ideological impact on the separate questions. The associations with the ideological predispositions were generally similar with the exception that the direct effect of cosmopolitanism is not significant $(B=0.55, p=.084)$ for the question on introducing political discussions for ordinary citizens.

10 One of the items included in our index concerns the rights of sexual minorities rather than cosmopolitan/nationalist values, but this has been shown to correlate strongly with similar dimensions (Inglehart, 1997).

${ }^{11}$ The exclusion of the remaining non-significant interaction effects is also warranted by their weak coefficients (see M3), meaning their substantial impact is in any case limited. Even if we run separate analyses for all interaction effects, the two non-significant interaction terms do not gain significance and the substantive impacts remain limited. We therefore remain confident that the two effects we focus upon are the most relevant.

${ }^{12}$ Even if the results for our control variables suggest there are few significant differences in terms of socio-demographic characteristics, suggesting that support for deliberative practices is fairly egalitarian in terms of descriptive representation (James, 2008). 
IDEOLOGY AND DELIBERATION

\section{List of Tables and Figures}

Table 1

Multivariate linear regression models examining support for deliberative practices

\begin{tabular}{|c|c|c|c|c|c|c|c|c|c|c|}
\hline & & \multicolumn{3}{|c|}{ M1 } & \multicolumn{3}{|c|}{ M2 } & \multicolumn{3}{|c|}{ M3 } \\
\hline & & Coef. & Robust SE & $P$ & Coef. & Robust SE & $P$ & Coef. & Robust SE & $P$ \\
\hline \multicolumn{11}{|l|}{ Independent variables } \\
\hline Left-right & & -0.22 & $(0.04)$ & 0.000 & -0.21 & $(0.04)$ & 0.000 & 0.12 & $(0.10)$ & 0.235 \\
\hline Nationalist-cosmopolitan & & 0.15 & $(0.04)$ & 0.000 & 0.12 & $(0.04)$ & 0.002 & 0.15 & $(0.13)$ & 0.230 \\
\hline \multicolumn{11}{|l|}{ Political awareness } \\
\hline Political knowledge & & & & & -0.02 & $(0.03)$ & 0.428 & 0.14 & $(0.12)$ & 0.245 \\
\hline Political interest & & & & & 0.39 & $(0.03)$ & 0.000 & 0.53 & $(0.11)$ & 0.000 \\
\hline \multicolumn{11}{|l|}{ Interactions } \\
\hline Political knowledge $\mathrm{x}$ left-righ & & & & & & & & -0.24 & $(0.13)$ & 0.072 \\
\hline Political interest $\mathrm{x}$ left-right & & & & & & & & -0.25 & $(0.12)$ & 0.042 \\
\hline $\begin{array}{l}\text { Political knowledge } \mathrm{x} \\
\text { cosmopolitan }\end{array}$ & Nationalist- & & & & & & & -0.06 & $(0.15)$ & 0.693 \\
\hline $\begin{array}{l}\text { Political interest } \mathrm{x} \\
\text { cosmopolitan }\end{array}$ & Nationalist- & & & & & & & 0.00 & $(0.14)$ & 0.977 \\
\hline \multicolumn{11}{|l|}{ Control variables } \\
\hline Age/100 & & & & & -0.09 & $(0.05)$ & 0.047 & -0.10 & $(0.05)$ & 0.026 \\
\hline Gender (1=Male) & & & & & -0.03 & $(0.02)$ & 0.066 & -0.03 & $(0.02)$ & 0.093 \\
\hline Education & & & & & -0.06 & $(0.03)$ & 0.102 & -0.05 & $(0.03)$ & 0.117 \\
\hline Full time employment $(1=$ Yes & & & & & -0.01 & $(0.02)$ & 0.376 & -0.02 & $(0.02)$ & 0.300 \\
\hline Satisfaction with democracy & & & & & -0.05 & $(0.05)$ & 0.288 & -0.05 & $(0.05)$ & 0.269 \\
\hline Internal efficacy & & & & & -0.07 & $(0.03)$ & 0.009 & -0.08 & $(0.03)$ & 0.006 \\
\hline External efficacy & & & & & 0.07 & $(0.04)$ & 0.135 & 0.07 & $(0.04)$ & 0.117 \\
\hline Political trust & & & & & -0.09 & $(0.06)$ & 0.118 & -0.09 & $(0.06)$ & 0.112 \\
\hline Constant & & 0.58 & $(0.03)$ & 0.000 & 0.53 & $(0.05)$ & 0.000 & 0.33 & $(0.09)$ & 0.000 \\
\hline $\mathrm{F}$ & & \multicolumn{3}{|c|}{$(2,1292)=31.25, p<0.001$} & \multicolumn{3}{|c|}{$(12,1201)=28.41, p<0.001$} & \multicolumn{3}{|c|}{$(16,1197)=24.21, p<0.001$} \\
\hline Adjusted $\mathrm{R}^{2}$ & & \multicolumn{3}{|c|}{0.05} & \multicolumn{3}{|c|}{0.19} & \multicolumn{3}{|c|}{0.19} \\
\hline $\mathrm{N}$ & & \multicolumn{3}{|c|}{1295} & \multicolumn{3}{|c|}{1214} & \multicolumn{3}{|c|}{1214} \\
\hline
\end{tabular}

Note: Entries are coefficients from linear regression analyses with robust standard errors in parentheses. 
IDEOLOGY AND DELIBERATION

\section{Figure 1}

Adjusted Predictions with $95 \% \mathrm{Cls}$

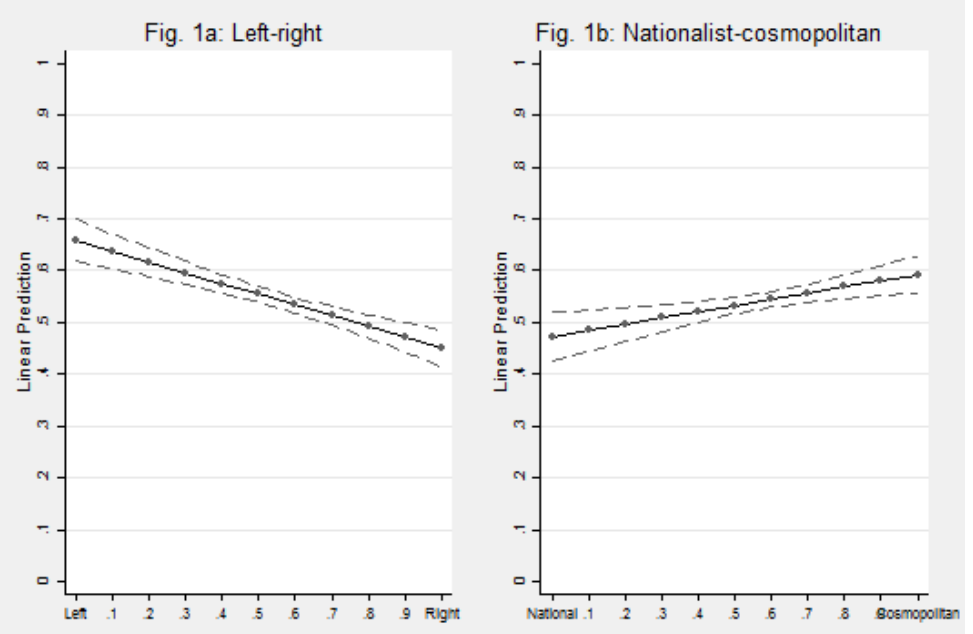

\section{Figure 2}

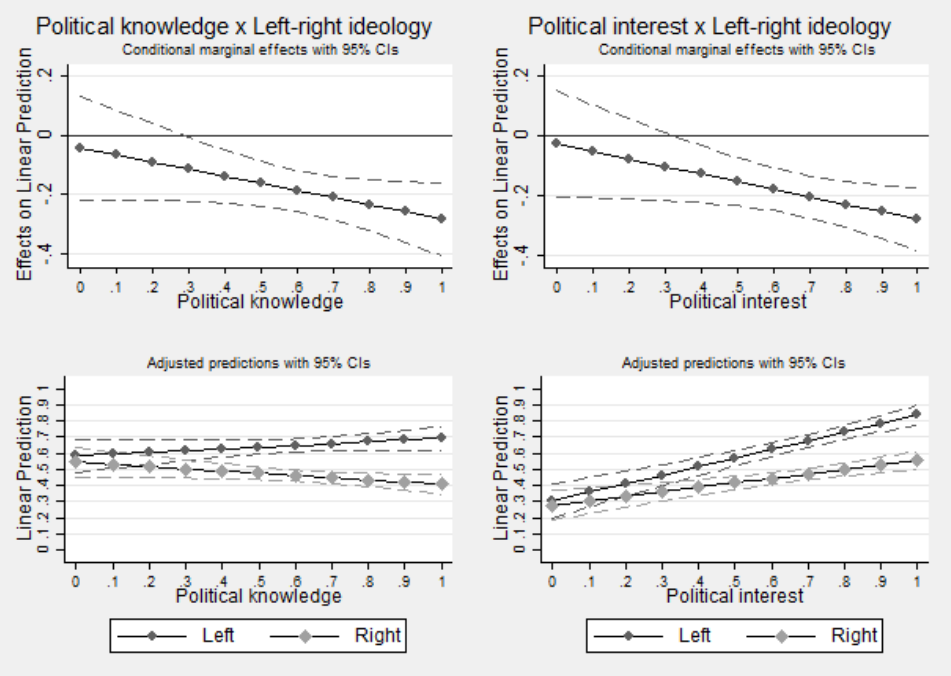




\section{APPENDIX}

Coding of variables and descriptive statistics

\begin{tabular}{|c|c|c|c|c|c|c|c|}
\hline Variable & Coding & $N$ & Mean & $S E$ & Min & $\operatorname{Max}$ & VIF \\
\hline \multicolumn{8}{|l|}{ DEPENDENT VARIABLE } \\
\hline Q1 & $\begin{array}{l}\text { Political discussions for ordinary citizens should be arranged } \\
\text { in support of representative democracy; answer on 4-point } \\
\text { scale }(0=\text { Totally disagree })\end{array}$ & 1502 & 1.94 & 0.83 & 0.00 & 3.00 & $\mathrm{~N} / \mathrm{A}$ \\
\hline Q2 & $\begin{array}{l}\text { I myself would like to participate in political discussions } \\
\text { arranged for ordinary citizens; answer on } 4 \text {-point scale } \\
(0=\text { Totally disagree })\end{array}$ & 1530 & 1.21 & 1.05 & 0.00 & 3.00 & $\mathrm{~N} / \mathrm{A}$ \\
\hline deliberative & $\begin{array}{l}\text { Additive index based on } \mathrm{Q} 1 \text { and } \mathrm{Q} 2 \text { coded to vary between } \\
0 \text { and } 1 \text { (1=highest extent of support). }\end{array}$ & 1469 & 0.53 & 0.27 & 0.00 & 1.00 & $\mathrm{~N} / \mathrm{A}$ \\
\hline \multicolumn{8}{|l|}{ INDEPENDENT VARIABLES } \\
\hline Left-right dimension & $\begin{array}{l}\text { Where would you place yourself on a scale where } 0 \text { stands for } \\
\text { left and } 10 \text { stands for right?; coded to vary between } 0 \text { and } 1 \\
(1=\text { Right). }\end{array}$ & 1388 & 0.56 & 0.21 & 0.00 & 1.00 & 1.13 \\
\hline $\begin{array}{l}\text { Nationalist-cosmopolitan } \\
\text { dimension }\end{array}$ & $\begin{array}{l}\text { Index based on answers to three proposals concerning the } \\
\text { future of Finland: 1) A multicultural Finland where people } \\
\text { are tolerant towards people from other countries; 2) A } \\
\text { Finland where the rights of sexual minorities are } \\
\text { strengthened; 3) A Finland with more immigration. All } \\
\text { responses } 0-10 \text { (10=very good proposal). Index coded to } \\
\text { vary between } 0 \text { and } 1 \text { (1=Cosmopolitan; Cronbach's } \\
\text { alpha=0.76). }\end{array}$ & 1587 & 0.56 & 0.22 & 0.00 & 1.00 & 1.16 \\
\hline \multicolumn{8}{|c|}{ POLITICAL AWARENESS (MODERATOR VARIABLES) } \\
\hline Political knowledge & $\begin{array}{l}\text { Number of correct answers to } 5 \text { factual questions on } \\
\text { political matters; coded to vary between } 0 \text { and } 1(1=5 \\
\text { correct). }\end{array}$ & 1587 & 0.57 & 0.28 & 0.00 & 1.00 & 1.27 \\
\hline Political interest & $\begin{array}{l}\text { How interested are you in politics? Answer on four-graded } \\
\text { scale coded to vary between } 0 \text { and } 1 \text { (1=Very interested })\end{array}$ & 1587 & 0.61 & 0.29 & 0.00 & 1.00 & 1.31 \\
\hline \multicolumn{8}{|l|}{ CONTROL VARIABLES } \\
\hline Age & 2015-Birth year, divided by 100 & 1587 & 0.51 & 0.20 & 0.18 & 0.94 & 1.31 \\
\hline Gender & Respondent's gender; $0=$ female, $1=$ male. & 1587 & 0.50 & 0.50 & 0.00 & 1.00 & 1.08 \\
\hline Education & $\begin{array}{l}\text { What is your highest educational attainment? Answer on } 7 \text { - } \\
\text { graded scale coded to vary between } 0 \text { and } 1 \text { ( } 1 \text { highest } \\
\text { educational attainment). }\end{array}$ & 1583 & 0.47 & 0.26 & 0.00 & 1.00 & 1.37 \\
\hline Employment & $\begin{array}{l}\text { Which of the following options best describes your life } \\
\text { situation? Answer included } 12 \text { possibilities, coded } \\
\text { dichotomously with } 1 \text { =full-time employment (at least } 32 \\
\text { hours per week), } 0=\text { anything else. }\end{array}$ & 1587 & 0.32 & 0.46 & 0.00 & 1.00 & 1.16 \\
\hline Satisfaction w. democracy & $\begin{array}{l}\text { How satisfied are you with the way democracy works in } \\
\text { Finland? Answer on four-graded scale coded to vary } \\
\text { between } 0 \text { and } 1 \text { (1=completely satisfied }) \text {. }\end{array}$ & 1568 & 0.60 & 0.19 & 0.00 & 1.00 & 1.18 \\
\hline Internal political efficacy & $\begin{array}{l}\text { Sometimes politics is so complicated that I don't really } \\
\text { understand what is going on. Answer on four-graded scale } \\
\text { coded to vary between } 0 \text { and } 1 \text { (1=disagree completely). }\end{array}$ & 1553 & 0.36 & 0.32 & 0.00 & 1.00 & 1.24 \\
\hline External political efficacy & $\begin{array}{l}\text { Index based on extent of agreement to } 4 \text { questions: } 1 \text { ) } \\
\text { Politicians don't care about the opinions of ordinary people; } \\
\text { 2) I cannot influence what the country's government and } \\
\text { parliament decide; 3) Parties are only interested in peoples' } \\
\text { votes, not their opinions; 4) It does not matter what parties } \\
\text { are in government, the policies still do not change. All } \\
\text { answers on four-graded scales 'Totally agree' -'Totally } \\
\text { disagree'; index coded to vary between } 0 \text { and } 1 \text { (1=highest } \\
\text { external efficacy; Cronbach's alpha=0.77). }\end{array}$ & 1459 & 0.48 & 0.24 & 0.00 & 1.00 & 1.53 \\
\hline Political trust & $\begin{array}{l}\text { How much do you trust each of the following actors? All } \\
\text { responses } 0-10(10=\text { complete trust }) \text {. Index based on trust } \\
\text { in Finnish President, Political parties, Parliament, Finnish } \\
\text { Government and Politicians; coded to vary between } 0 \text { and } \\
1 \text { ( } 1 \text { complete trust; Cronbach's alpha }=0.91) \text {. }\end{array}$ & 1587 & 0.63 & 0.17 & 0.00 & 1.00 & 1.30 \\
\hline
\end{tabular}

